\title{
Contraception Recommendations With Analytical Hierarchy Process (AHP) and Weighted Product Methods (WP)
}

\author{
Audi Bayu Yuliawan ${ }^{1^{*}}$, Nur Hayatin ${ }^{2}$, Yuvis Azhar ${ }^{3}$ \\ a),b) Universitas Muhammadiyah Malang \\ *Corresponding Author \\ e-mail: audibayu04@gmail.com
}

\begin{abstract}
Planning Program $(K B)$ as one way to reduce the high rate of pregnancy. Contraceptives used in family planning programs have various types. In addition to the presence of contraception for women, contraception is also available for men. It's just that the problem at this time, lack of knowledge will choose contraception in accordance with health conditions. The limited time, place and expertise of experts to always provide information is one of the obstacles to getting complete information. Decision Support System is a knowledge-based computer information system that is used to support decision making in a problem. This system will later use the Analytical Hierarchy Process method, this method is a method that makes decision makers to get priority scale or consideration of experience, views, intuition and original data. Not only that this system will also use the Weighted Product (WP) method to maximize the performance of AHP in ranking the final results. This application is made using the Android programming language with Android Studio as the platform. In this application will later display recommendations for selecting contraceptives that are suitable for a patient.
\end{abstract}

Keyword: $A H P, D D S$, Contraception, $K B, W p$.

\section{INTRODUCTION}

Indonesia is a country with the most number 4 population in the world. The number of population growth in Indonesia is increasingly growing rapidly due to high birth rates. According to the National Statistics Agency based on the results of the 2010 population census, Indonesia's population has reached more than 250 million people. This very high number of government makes a policy to slow down the rate of population growth by holding a Family Planning (KB) program.

The family planning program is a program that implements planning and limiting the number of births using contraceptives. There are various types of contraceptives used to implement this program. Various types of contraceptives cause people to choose which contraception is suitable for them, but this is not an easy matter because not all contraceptives are always suitable for their users. The choice of contraception itself must also be seen from the physical and mental conditions of the user in order to work optimally. Most of the people in determining the contraceptive used are still based on "what the neighbors say" so this certainly reduces the effectiveness of the contraceptive, as a result there are quite a lot even though they already have family planning still have children afterwards.

In the development of increasingly advanced technology, the solution to this problem is the implementation of a web-based decision-making system that can help facilitate contraceptive users to determine suitable contraceptives. Decision Support System is a knowledge-based computer information system that is used to support decision making in a problem [1] [2] [3] [4]. This system will also be supported by using the Process hierarchy process (AHP) method. AHP itself is a system that makes decision makers to get priority scales or considerations of experience, views, intuition and original data [5] [6] [7] [8]. Not only that this system will also use the Weighted Product (WP) method to maximize the performance of AHP in ranking the final results [9]. In other words, this system not only takes decisions based on numbers, but there are other considerations so that the resulting decisions will be more accurate and effective. With this system, it will greatly help users to get a more accurate. 


\section{RESEARCH METHOD}

\subsection{System Implementation}

In the implementation of the system in the application of recommendations this contraceptive will be divided into 5 stages, namely data, extraction, AHP decision model which will be stored in the database, selection, and the last is the result.

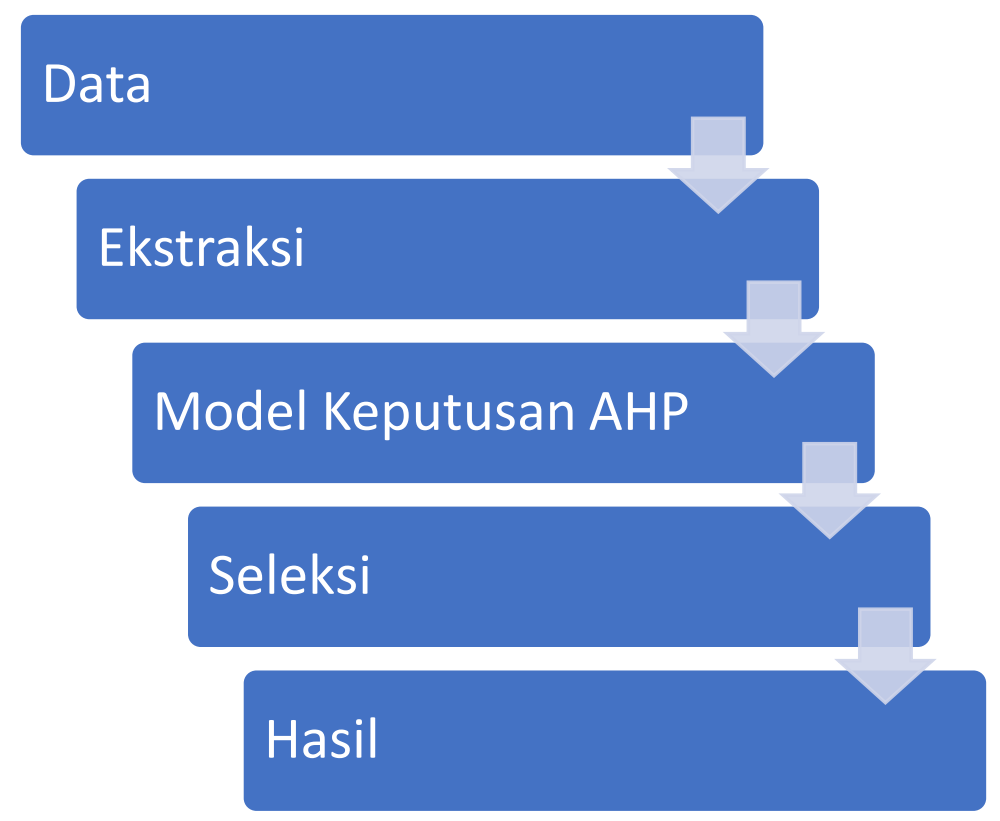

Figure 1 Implementation Stages

\subsubsection{Data}

At this data stage contains input data based on the criteria that have been determined (can be seen in the research variable subchapter) to get information about the patient's condition. Following is an example of implementation at the Data stage :

A patient uses this application and has the following conditions :

- Age 35 years

- $50 \mathrm{~kg}$ weight

- Have used KB (injecting)

- 2-year contraceptive usage period

- The menstrual period is not smooth

- Suffer from heart disease

- Not just giving birth

- Have allergies to rubber or the like

- Do not want surgery

\subsubsection{Extraction}

At this extraction stage contains extraction on the tada that has been obtained in order to retrieve important variables which will later become the key of the process that will be carried out by the system. Following are examples of implementation at the Extraction stage : 
Jurnal Perempuan dan Anak (JPA), Vol. 1 No. 1, Februari 2021, pp. 1-14

ISSN: 2442-2614 print | 2716-3253 online

Table 1 Extraction of criteria and contraceptives

\begin{tabular}{ccccccc}
\hline Alat & Berat Badan & Jangka Waktu (bagi yg pernah) & Periode Mens & Gangguan kesehatan & Baru Melahirkan & Jumlah Nilai \\
\hline IUD & 1 & 1 & 1 & 1 & 1 & 5 \\
\hline MOP & 1 & 1 & 1 & 1 & 1 & 5 \\
\hline MOW & 1 & 1 & 1 & 0 & 1 & 4 \\
\hline Kondom & 1 & 1 & 1 & 0 & 1 & 5 \\
\hline Suntik & 1 & 0 & 0 & 0 & 1 & 2 \\
\hline Pil & 1 & 0 & 0 & 0 & 1 & 2 \\
\hline Implan & 1 & 1 & 0 & 0 & 3 \\
\hline
\end{tabular}

The purpose of numbers 1 and 0 above is as a value giver of predetermined criteria and compared with the condition of the patient or application user, for example in the weight column contains a value of 1 because the user has a weight of $50 \mathrm{~kg}$ so it is safe to use all contraceptives. Then in the column health problems MOW contraceptives, injections, pills and implants are 0 because the user has heart disease which is a taboo for the contraceptive. Furthermore, the numbers obtained in the column of the amount of value will be used as calculation capital in the stages of the AHP Decision Model.

\subsubsection{AHP Decision Model}

AHP arranges complex decision situations in terms of hierarchical decision criteria and related priorities, balances interactions between criteria and synthesizes information into preference vectors between alternatives. In general, the stages in the AHP method can be seen as follows :

- Determine Priority / Weight Criteria

- Determine Alternative Priorities

- Alternative ranking

There are 3 steps or stages in the AHP method. For the first stage, in determining the criteria weight, there are several more sub-stages, namely composing a pairwise comparison matrix, calculating the weight of the criteria to test the consistency of the criteria weight. Whereas in the second stage in determining alternative priorities, alternative weights are calculated for benefit quantitative criteria, alternative weights for quantitative criteria for cost and alternative weights for qualitative criteria. And finally, is the ranking in AHP [10].

In the process of hierarchical analysis, in general the problem solving is carried out in the following stages:

\subsubsection{Problems}

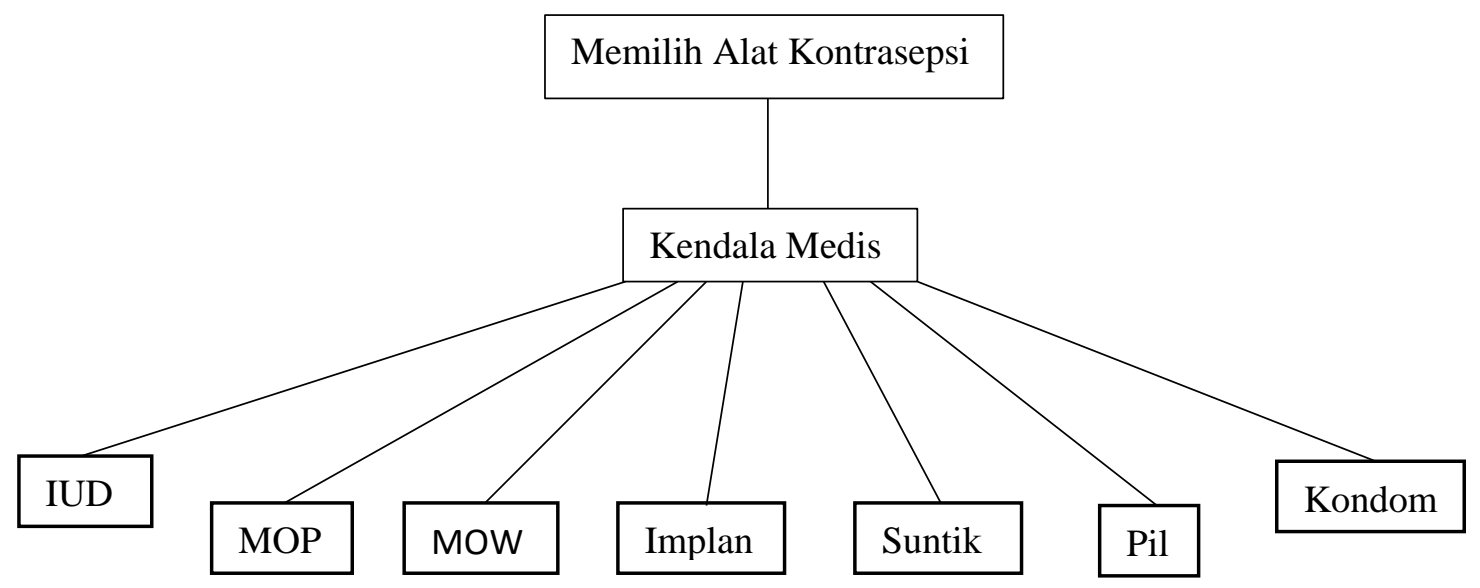

Figure 2 Hierarchy of Problems 
2.1.3.2 Pairewise Comparison Matrix

Table 2 Pairwise comparison matrix

\begin{tabular}{ccccccc}
\hline Kendala Medis & Kondom & Suntik & Pil & Implan & IUD & MOP \\
\hline Kondom & 1 & $5 / 2$ & $5 / 2$ & $5 / 3$ & 1 & 1 \\
\hline Suntik & $2 / 5$ & 1 & 1 & $2 / 3$ & $2 / 5$ & $2 / 5$ \\
\hline Pil & $2 / 5$ & 1 & 1 & $2 / 3$ & $2 / 5$ & $2 / 5$ \\
\hline Implan & $3 / 5$ & $3 / 2$ & $3 / 2$ & 1 & $3 / 5$ & $3 / 5$ \\
\hline IUD & 1 & $5 / 2$ & $5 / 2$ & $5 / 3$ & 1 & 1 \\
\hline MOP & 1 & $5 / 2$ & $5 / 2$ & $5 / 3$ & 1 & 1 \\
\hline MOW & $4 / 5$ & 2 & 2 & $4 / 3$ & $4 / 5$ & $4 / 5$ \\
\hline
\end{tabular}

2.1.3.3 Synthesize Comparisons

Table 3 Normalized Comparative Matrices

\begin{tabular}{cccccccc}
\hline Kendala Medis & Kondom & Suntik & Pil & Implan & IUD & MOP & MOW \\
\hline Kondom & 1 & $5 / 2$ & $5 / 2$ & $5 / 3$ & 1 & 1 & $5 / 4$ \\
\hline Suntik & $2 / 5$ & 1 & 1 & $2 / 3$ & $2 / 5$ & $2 / 5$ & $2 / 4$ \\
\hline Pil & $2 / 5$ & 1 & 1 & $2 / 3$ & $2 / 5$ & $2 / 5$ & $2 / 4$ \\
\hline Implan & $3 / 5$ & $3 / 2$ & $3 / 2$ & 1 & $3 / 5$ & $3 / 5$ & $3 / 4$ \\
\hline IUD & 1 & $5 / 2$ & $5 / 2$ & $5 / 3$ & 1 & 1 & $5 / 4$ \\
MOP & 1 & $5 / 2$ & $5 / 2$ & $5 / 3$ & 1 & 1 & $5 / 4$ \\
\hline MOW & $4 / 5$ & 2 & 2 & $4 / 3$ & $4 / 5$ & $4 / 5$ & 1 \\
\hline Jumlah & 5,2 & 13 & 13 & 8,8 & 5,2 & 5,2 & 6,5
\end{tabular}

Then the value of each entry in the same row is averaged.

Table 4 Normalization matrix on average

\begin{tabular}{ccccccccc}
\hline Kendala Medis & Kondom & Suntik & Pil & Implan & IUD & MOP & MOW & Rata-Rata \\
\hline Kondom & 0,19 & 0,19 & 0,19 & 0,19 & 0,19 & 0,19 & 0,19 & 0,19 \\
\hline Suntik & 0,08 & 0,08 & 0,08 & 0,08 & 0,08 & 0,08 & 0,08 & 0,08 \\
\hline Pil & 0,08 & 0,08 & 0,08 & 0,08 & 0,08 & 0,08 & 0,08 & 0,08 \\
\hline Implan & 0,12 & 0,12 & 0,12 & 0,12 & 0,12 & 0,12 & 0,12 & 0,12 \\
\hline IUD & 0,19 & 0,19 & 0,19 & 0,19 & 0,19 & 0,19 & 0,19 & 0,19 \\
\hline MOP & 0,19 & 0,19 & 0,19 & 0,19 & 0,19 & 0,19 & 0,19 & 0,19 \\
\hline MOW & 0,15 & 0,15 & 0,15 & 0,15 & 0,15 & 0,15 & 0,15 & 0,15 \\
\hline Jumlah & 1,00 & 1,00 & 1,00 & 1,00 & 1,00 & 1,00 & 1,00 & 1,00 \\
\hline
\end{tabular}

2.1.3.4 Evaluation of consistency. For the problem of choosing contraceptives, the following steps are taken :

Table 5 Weighted comparison matrix

\begin{tabular}{ccccccccc}
\hline Kendala Medis & Kondom & Suntik & Pil & Implan & IUD & MOP & MOW & Jumlah \\
\hline Kondom & $1(0,19)$ & $5 / 2(0,08)$ & $5 / 2(0,08)$ & $5 / 3(0,12)$ & $1(0,19)$ & $1(0,19)$ & $5 / 4(0,15)$ & 1,36 \\
\hline Suntik & $2 / 5(0,19)$ & $1(0,08)$ & $1(0,08)$ & $2 / 3(0,12)$ & $2 / 5(0,19)$ & $2 / 5(0,19)$ & $2 / 4(0,15)$ & 0,56 \\
\hline Pil & $2 / 5(0,19)$ & $1(0,08)$ & $1(0,08)$ & $2 / 3(0,12)$ & $2 / 5(0,19)$ & $2 / 5(0,19)$ & $2 / 4(0,15)$ & 0,56 \\
\hline Implan & $3 / 5(0,19)$ & $3 / 2(0,08)$ & $3 / 2(0,08)$ & $1(0,12)$ & $3 / 5(0,19)$ & $3 / 5(0,19)$ & $3 / 4(0,15)$ & 0,83 \\
\hline IUD & $1(0,19)$ & $5 / 2(0,08)$ & $5 / 2(0,08)$ & $5 / 3(0,12)$ & $1(0,19)$ & $1(0,19)$ & $5 / 4(0,15)$ & 1,36 \\
\hline MOP & $1(0,19)$ & $5 / 2(0,08)$ & $5 / 2(0,08)$ & $5 / 3(0,12)$ & $1(0,19)$ & $1(0,19)$ & $5 / 4(0,15)$ & 1,36 \\
\hline MOW & $4 / 5(0,19)$ & $2(0,08)$ & $2(0,08)$ & $4 / 3(0,12)$ & $4 / 5(0,19)$ & $4 / 5(0,19)$ & $1(0,15)$ & 1,08 \\
\hline
\end{tabular}


Next, calculate the consistency vector

Table 6 Calculation of Consistency Vector

\begin{tabular}{ccc}
\hline Kendala Medis & Jumlah/Vektor Prioritas & Vektor Konsistensi \\
\hline Kondom & $1,36 / 0,19$ & 7,16 \\
Suntik & $0,56 / 0,08$ & 7 \\
\hline Pil & $0,56 / 0,08$ & 7 \\
\hline Implan & $0,83 / 0,12$ & 6,91 \\
\hline IUD & $1,36 / 0,19$ & 7,16 \\
\hline MOP & $1,36 / 0,19$ & 7,16 \\
\hline MOW & $1,08 / 0,15$ & 7,2 \\
\hline & Rata - rata (lambda) & 7,08 \\
\hline
\end{tabular}

Lambda value $=7.08$

Next calculate the consistency index (CI), where $n=7$ (alternative value compared)

$\mathrm{CI}=\left(\lambda \_\max -\mathrm{n}\right) /(\mathrm{n}-1)=(7.08-7) /(7-1)=0.013$

For $\mathrm{n}=7$, random index $(\mathrm{RI})=1.32$ so the consistency ratio

$\mathrm{CR}=\mathrm{CI} / \mathrm{RI}=0.013 / 1.32=0.010$

Calculation Results CR shows the value of $\mathrm{CR}=0.010$ means that the response is quite consistent because $\mathrm{CR}<10 \%$. So the final result shows the user is advised to choose contraceptives in the form of condoms, IUDs, and MOP because they have the highest priority value of 0.19 .

Table 7 Final Summary

1

\begin{tabular}{|c|cccc|c|c|cc} 
Kendala & Kondom & Suntik & pil & Implan & IUD & MOP & MOW & Prioritas \\
Medis & & & & & & & & \\
\hline Kondom & 0,19 & 0,19 & 0,19 & 0,19 & 0,19 & 0,19 & 0,19 & 0,19 \\
\hline Suntik & 0,08 & 0,08 & 0,08 & 0,08 & 0,08 & 0,08 & 0,08 & 0,08 \\
\hline Pil & 0,08 & 0,08 & 0,08 & 0,08 & 0,08 & 0,08 & 0,08 & 0,08 \\
\hline Implan & 0,12 & 0,12 & 0,12 & 0,12 & 0,12 & 0,12 & 0,12 & 0,12 \\
\hline IUD & 0,19 & 0,19 & 0,19 & 0,19 & 0,19 & 0,19 & 0,19 & 0,19 \\
MOP & 0,19 & 0,19 & 0,19 & 0,19 & 0,19 & 0,19 & 0,19 & 0,19 \\
\hline MOW & 0,15 & 0,15 & 0,15 & 0,15 & 0,15 & 0,15 & 0,15 & 0,15 \\
\hline
\end{tabular}

\subsubsection{Selection}

At this selection stage, the final selection will be done after the results are obtained from the AHP decision stages. This stage will use the Weighted Product (WP) method in the selection process. Weighted Product Method (WP) is a multiplication method to connect the attribute rating, where the rating of each attribute must be raised first with the weight of the attribute in question [9]. The results of the previous stages produced 3 choices, namely condoms, IUDs and MOP. Furthermore, the final selection of the three tools will be carried out using ranking algorithms based on patient preference criteria. The following is an example of the implementation of the Selection stage: 
Table 8 Ranking of Patient Preference Criteria

\begin{tabular}{cccccc}
\hline Alat & \multicolumn{5}{c}{ Kriteria } \\
\cline { 2 - 6 } & $\begin{array}{c}\text { Kemudahan penggunaan (operasi } \\
\text { / non operasi) }\end{array}$ & $\begin{array}{c}\text { Harga (mahal / } \\
\text { murah) }\end{array}$ & $\begin{array}{c}\text { Jangka Pemakaian (Panjang / } \\
\text { Pendek) }\end{array}$ & $\begin{array}{c}\text { Efek(punya alergi atau } \\
\text { tidak) }\end{array}$ & Keberhasilan \\
& 1 & & & & 0 \\
\hline Kondom & 1 & 1 & 1 & 1 & 0.5 \\
\hline IUD & 0 & 1 & 1 & 1 & 1 \\
\hline MOP & & & 1 & 1 & 1 \\
\hline
\end{tabular}

$\sum w j=1 . w j$ is a positive value for the profit attribute, and is negative for the cost attribute. Criteria for Ease of Use, Effects, and success are profit criteria. While the criteria for price, and usage period are cost criteria Initial weights $\mathrm{W}=(3,2,4,4,5)$, will be corrected so that the total weight $\sum \mathrm{Wj}=1$, by :

$$
\begin{aligned}
& W_{j}=\frac{W_{j}}{\sum W_{j}} \\
& W_{1}=\frac{3}{3+2+4+4+5}=\frac{3}{18}=0,1666 \\
& W_{2}=\frac{2}{3+2+4+4+5}=\frac{2}{18}=0,1111 \\
& W_{3}=\frac{4}{3+2+4+4+5}=\frac{4}{18}=0,2222 \\
& W_{4}=\frac{4}{3+2+4+4+5}=\frac{4}{18}=0,2222 \\
& W_{5}=\frac{5}{3+2+4+4+5}=\frac{5}{18}=0,2777
\end{aligned}
$$

Then vector $\mathrm{S}$ is calculated based on the equation

$$
S_{i}=\prod_{j}^{n}=X_{i j} w_{j} \text { dengan } \mathrm{i}=1,2, \ldots, \mathrm{m}
$$

as follows

$$
\begin{aligned}
& S_{1}=\left(1^{0,1666}\right)\left(1^{-0,1111}\right)\left(1^{-0,2222}\right)\left(0^{0,2222}\right)\left(0.5^{0,2777}\right)=0 \\
& S_{2}=\left(1^{0,1666}\right)\left(1^{-0,1111}\right)\left(1^{-0,2222}\right)\left(1^{0,2222}\right)\left(1^{0,2777}\right)=1 \\
& S_{3}=\left(0^{0,1666}\right)\left(1^{-0,1111}\right)\left(1^{-0,2222}\right)\left(1^{0,2222}\right)\left(1^{0,2777}\right)=0
\end{aligned}
$$

The vector value that will be used for ranking can

calculated based on the equation

$$
\begin{gathered}
V_{i}=\frac{\Pi_{j}^{n}=1 x_{i j w j}}{\Pi_{j}^{n}=1\left(x_{j^{*}}\right)^{w j}} ; \text { dengan } \mathrm{i}=1,2, \ldots, \mathrm{m} \text { sebagai berikut : } \\
V_{1}=\frac{0}{0+1+0}=0
\end{gathered}
$$




$$
\begin{aligned}
& V_{2}=\frac{1}{0+1+0}=1 \\
& V_{3}=\frac{0}{0+1+0}=0
\end{aligned}
$$

The biggest $\mathrm{V}$ value is at V2 value.

\subsubsection{Result}

At this stage the results will contain the recommendations that will be issued by the system after going through the previous stages. For example, according to the calculation of the previous stages the value of V2 is the highest value so that the IUD is the best alternative that is obtained by the system for the user.

\section{RESULTS and DISCUSSION}

\subsection{Start Menu}

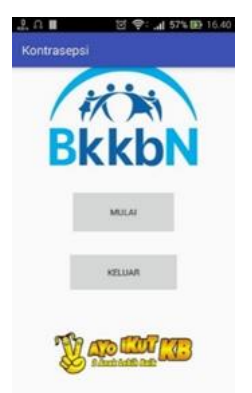

Figure 3 Start Menu

This initial menu is a menu that is displayed first when this application is turned on or used later. In this initial menu there are 2 selection buttons or 2 features to choose to the next step. The first option is "START", this option is used for users who want to use this application as a consultation tool to get recommendations for contraception. If option 1 is selected then the next step will go to the menu that has been provided by the operator of this application. The second option is the "OUT" menu on this menu, which is used to exit this application.

\subsection{Second Menu}

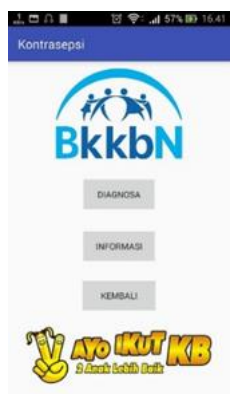

Figure 4 Second Menu Display

This page is an open menu page after pressing the "START" button on the main page. On this page has 3 buttons that have different uses in the first button is a diagnostic button which when pressed is useful to enter the consultation page or page to diagnose the patient based on medical assessment and patient preferences which will bring up the output in the form of recommendations for contraception patient. The 
second button is the info button, this button serves to direct the user to a menu that contains complete information about contraceptives so that users can understand and gain insight into contraceptives. The three back buttons function to return to the main menu if the user wants to discourage him from diagnosing or opening the info page.

\subsection{Diagnosis}

This diagnostic page is the page that the user uses to make a diagnosis in order to choose what contraception is most suitable for the condition of the user. This page is divided into 3 parts, namely the first page of medical criteria input, which means input in the form of health conditions and other disorders that affect the course of contraceptive use in accordance with the user's condition. The second is the input page according to patient preference, meaning input in the form of criteria that the patient wants. The third is the results page which will display the results of the recommendations that have been carried out based on input by the user.

\subsubsection{Input page Criteria based on medical assessment}

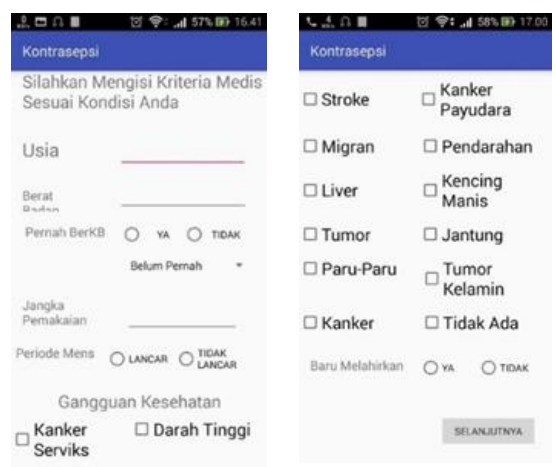

Figure 5 Input Display of Medical Assessment Criteria

The first page of the diagnostic menu contains input that must be done by users of this application. Input contains the latest health conditions of users and other disturbances that affect the use of family planning devices. As in Figure 4.3 the input which is contained in the form of health problems such as cancer, high blood pressure, stroke, breast cancer, migrants, bleeding, liver, diabetes, tumors, heart, lung, cervical cancer, and genital tumors. This criterion is very important because each contraceptive cannot be used by users who have certain health problems because it will be harmful to the user when used. For example, people with heart disease cannot use hormonal contraceptives because they will affect their heart and are advised to use non-hormonal contraceptives. In addition there are also other conditions that are taken into consideration to use contraceptives, namely the period of use because hormonal contraceptives can only be used for 2 years if more than this will result in the user's body condition. The most visible result is a nonsmooth menstrual period, it is a signal from the body that the contraceptive used is not in accordance with the user's body condition. Furthermore, it is only giving birth or not because there are several contraceptives that will be dangerous if used by newborn users. 


\subsubsection{The Input Criteria page is based on patient preferences}

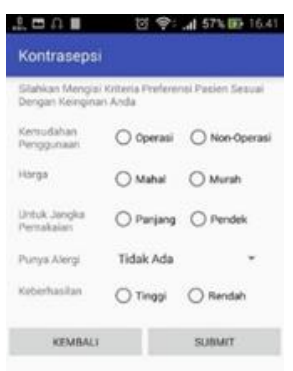

Figure 6 Input Display of Patient Preference Criteria

The second page of the diagnosis menu is the criteria input page based on patient preferences or criteria according to the patient's wishes. On this page there are criteria that are usually considered by users when choosing a contraceptive tool. The first is ease of use or method of use. Contraception is divided into 2 types in how to use it, namely surgery and non-surgery. Some patients who use contraceptives do not like to do family planning by using contraceptives that operate for fear and are expensive, there are also patients because they do not want to have more offspring and do not want to be bothered if they have to do family planning which must be routinely used. check regularly so they choose contraceptive methods or methods that use it by undergoing surgery. Second is the price criteria, of course, the public must choose those that have cheap prices, but there are some patients who choose to use expensive contraceptives because they believe that the contraceptive is expensive, the contraception is good and has maximum results. The three periods of use of this criterion are almost the same as the first criteria but are more focused on their usage time, there are users who prefer to use contraceptive contraceptives because the price is cheap and there are more users who like to use contraceptives that are used once but for a long time though they have to pay a higher price. These four allergies are actually only for a number of contraceptives such as condoms, implants, and IUDs because these contraceptives come into direct contact with users such as condoms cannot be used by people who are allergic to rubber, implants and IUDs for allergic users against copper and other metal materials. Fifth, the success rate of course users will choose contraceptives that have maximum results and have a high success rate.

\subsection{Result Page}

\subsubsection{Main Results}

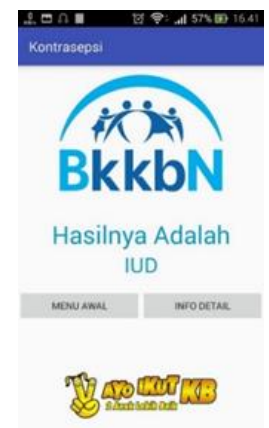

Figure 7 Display of Main Results 
This third page is a page that displays the results of diagnoses from users who have entered criteria data that is appropriate to the medical conditions and conditions of the user's desire. On this page the user will be shown the recommendation of the name of the contraceptive that is most suitable for use based on the tool that gets the highest value from the stage that has been done. In addition to displaying results there are other features that are on this page, namely the button back to the start menu and the button for detailed information from the answers obtained by the user.

\subsubsection{Detail Results}

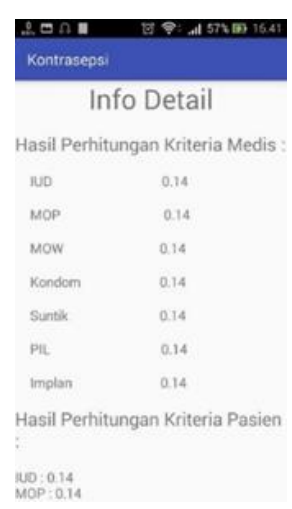

Figure 7 Display of Detail Results

On this page there are 2 results, but the highest results that have been taken through 2 calculation processes have been used because the results are the most valid and the best results. The first result is the temporary results obtained after processing medical criteria data only. The processing that is done to get the results shown on this page, the first is the process of using the AHP method that is done on medical criteria data with the output in the form of temporary results such as the example in figure 4.6. namely using Weighted Product with selection based on criteria that are in accordance with patient preferences. That way you will get maximum results.

\subsection{Info Page}

This page is an advanced page when selecting the info button on the second page. The info page contains various types of contraceptives that can be used. Not only that this page also provides a variety of complete information for users so that they can add insight into contraceptives. In the info menu consists of 2 pages, the first contains a list of contraceptives that can be selected. Second, when the tool name button is pressed, it will enter the page that displays information about the tool.

\subsubsection{Options Menu Tool Info}

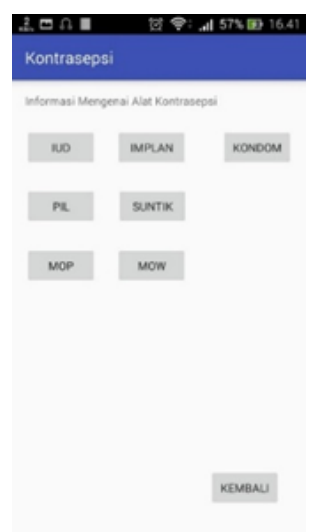

Figure 8 Selection menu of Contraception Tool Information 
This first page contains a list of contraceptives in the form of buttons that can later be pressed to then continue on the page that contains information about the contraceptive. This page temporarily contains 7 choices because according to the selected case study, the Kalikejambon village has only 7 types of contraceptive methods or methods that are used including the IUD, MOP (Male Operating Method), MOW (Female Operation Method), condoms, implants pills and injections. Of each tool has different terms and criteria that must be fulfilled if you want to use it. Therefore, on this information page, all information about contraceptive tools or methods will also be explained and also help ease the task of family planning workers in educating the public about contraceptives.

\subsubsection{Information Display Menu About Tools}

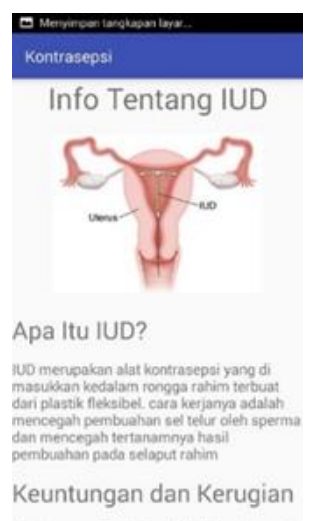

Figure 3.8 Tool Info

The second page from this info menu contains detailed information about contraceptive tools or methods selected on the previous tool selection page. The information presented on this page contains what the tool is, how it works, the side effects that are caused, who may use it and who is not allowed to use the tool, and other important information. This page is also equipped with contraceptive tools or methods so that users can know more about what contraceptive methods or methods they will use later.

\subsection{Testing}

After implementing and getting the results, the next step is the testing phase. The recommendation of this contraceptive with the diagnostic data obtained randomly that will be corrected by an expert in the content and contraceptive fields and the results of expert answers will be compared with the results of the application to get the percentage of application accuracy so that when used in the community generally no errors occur that harm users.

Table 9 Comparative Results from Experts and Applications

\begin{tabular}{ccc}
\hline Aplikasi & Alat yang Direkomendasikan & Keterangan \\
\hline IUD & IUD \\
\hline IUD & IUD,Pil,Suntik \\
\hline IUD, Suntik, Pil & Pil \\
\hline IUD, Kondom & Kondom, Pil \\
\hline IUD & IUD \\
\hline
\end{tabular}




\begin{tabular}{|c|c|c|}
\hline Pil & Pil & \\
\hline IUD & IUD & \\
\hline IUD & IUD & \\
\hline Suntik & Pil, Suntik & \\
\hline IUD & Boleh Semua & \\
\hline IUD & IUD & \\
\hline Implant & Implant, Pil & \\
\hline IUD & IUD & \\
\hline IUD & Pil & Tidak Semua \\
\hline IUD & IUD & \\
\hline IUD & IUD & \\
\hline IUD & Boleh Semua & \\
\hline IUD & IUD & \\
\hline IUD & IUD & \\
\hline IUD, Kondom, Suntik, Implant & Boleh Semua & \\
\hline IUD, Suntik, Pil, Implant, Kondom & Kondom, Pil & \\
\hline IUD & IUD & \\
\hline IUD & IUD & \\
\hline IUD, Suntik, Pil, Implant, Kondom & IUD, Pil & \\
\hline IUD & IUD & \\
\hline IUD & IUD & \\
\hline IUD, Suntik, Pil & Boleh Semua & \\
\hline IUD, MOP, Pil & Pil & \\
\hline IUD & IUD & \\
\hline Implant, Kondom & Boleh Semua & \\
\hline IUD, Suntik, Pil & Pil & \\
\hline IUD & IUD & \\
\hline IUD & IUD & \\
\hline IUD & IUD & \\
\hline IUD & IUD & \\
\hline IUD & IUD & \\
\hline Pil, Suntik & Pil, Suntik & \\
\hline IUD & IUD & \\
\hline IUD & IUD & \\
\hline Pil, Suntik & Pil, Suntik & \\
\hline IUD & IUD & \\
\hline IUD & IUD & \\
\hline
\end{tabular}


Jurnal Perempuan dan Anak (JPA), Vol. 1 No. 1, Februari 2021, pp. 1-14

ISSN: 2442-2614 print | 2716-3253 online

\begin{tabular}{cc}
\hline IUD & IUD \\
\hline IUD, Suntik, Pil, Implant & Pil \\
\hline Kondom & Kondom \\
\hline IUD & IUD \\
\hline IUD & IUD, Pil \\
\hline IUD, Suntik, Pil, Implant & Pil \\
\hline IUD & IUD \\
\hline IUD & Boleh Semua \\
\hline
\end{tabular}

From the comparison table above shows there is one difference from the results of the expert with the application. The difference lies in patient number 14 where the results of the application recommend IUD contraception while experts recommend contraceptive pills. After a review of the source of the difference lies in the condition of patients who have used contraception in the form of kb pills for 3 years. This causes the system on the application to automatically remove pills from the list because according to the provisions of maximum hormonal contraception only be used for a maximum of 2 years. If you want to use more pills, you have to switch to another contraception for a while before using contraceptive pills again. However, experts seem to have different views on this matter. According to experts using hormonal contraceptives for a long time there is no problem as long as it does not adversely affect the patient's condition.

With this it can be concluded that the accuracy of the application of the following contraceptive recommendations is

(Number of Same Results) / (Total Amount) X $100=49 / 50$ X $100=98 \%$

These results indicate that the application is quite accurate in making decisions recommending contraceptives to its users with $98 \%$ truth accuracy.

\section{CONCLUSION}

Based on the details of the research presented by the authors above, it can be concluded that this study aims to help contraceptive users in choosing contraceptives that are good and true by combining two methods. The results of combining the two methods resulted in an accuracy of $98 \%$. With this, it is expected to help increase fertile age couples to be aware of implementing family planning programs so that they can help implement government programs to reduce the rate of population development.

\section{REFERENCES}

[1] A. B. H. P. Selçuk Gören, "A Framework to Incorporate Decision-Maker Preferences Into Simulation Optimization to Support Collaborative Design," IEEE TRANSACTIONS ON SYSTEMS, MAN, AND CYBERNETICS: SYSTEMS, vol. 47, no. 2, pp. 229 - 237, 2016.

[2] S. B. S. S. Madavan Rengaraj, "Multi-criteria decision-making methods for grading highperformance transformer oil with antioxidants under accelerated ageing conditions," IET Generation, Transmission \& Distribution, vol. 11, no. 16, pp. 4051-4058 , 2017. 
[3] Z. M. Y. S. Y. L. H. Y. G. W. Lingjie Sun, "Research on multi-attribute decision-making in condition evaluation for power transformer using fuzzy AHP and modified weighted averaging combination," IET Generation, Transmission \& Distribution, vol. 10, no. 15, pp. 3855 - 3864, 2016.

[4] V. D. D. E. G. S. a. C. V. C. M. B. Ribeiro, "Prioritization of Critical Success Factors In The Process of Software Development," IEEE LATIN AMERICA TRANSACTIONS, vol. 15, no. 1, pp. 137 - 144 , 2017.

[5] Z. L. N. D. A. S. A. R. S. S. A. F. S. DAN WANG, "Case-Based Reasoning for Product Style Construction and Fuzzy Analytic Hierarchy Process Evaluation Modeling Using Consumers Linguistic Variables," IEEE Access, vol. 5, pp. 4900 - 4912, 2017.

[6] S. Z. L. H. L. E. P. C. a. C.-H. C. Edward Huang, "Improving Analytic Hierarchy Process Expert Allocation Using Optimal Computing Budget Allocation," IEEE TRANSACTIONS ON SYSTEMS, MAN, AND CYBERNETICS: SYSTEMS, vol. 46, no. 8, pp. 1140 - 1147, 2015.

[7] M. H. Muhammad Fadlan, "Terapan Kombinasi Metode dan Analytical Hierarchy Process Pada Perekomendasian Penerima Beasiswa Peningkatan Prestasi Akademik (Studi Kasus STMIK PPKIA TARAKANITA RAHMAWATI)," SIMETRIS, vol. 8, no. 2, pp. 663-670, 2017.

[8] Kusumadewi, dkk. Fuzzy Multi-Atribute Decision Making (Fuzzy MADM), Yogyakarta: Graha Ilmu, 2006.

[9] R. Ishak, "Sistem Keputusan Pemilihan Penyuluhan Lapangan Keluarga Berencana Teladan Dengan Metode Weighted Product," Jurnal Ilmiah ILKOM, vol. 8, no. 3, pp. 160-166, 2016.

[10] N. L. N. S. Eko Darmanto, "Penerapan Metode AHP (Analytical Hierarchy Process) Untuk Menentukan Kualitas Gula Tumbu," Simetris, vol. 5, no. 1, pp. 75-82, 2014. 